\title{
Inhibition of Glycosylation of Herpes Simplex Virus Glycoproteins: Identification of Antigenic and Immunogenic Partially Glycosylated Glycopeptides on the Cell Surface Membrane
}

\author{
JOSEPH GLORIOSO, ${ }^{* 1}$ MARK S. SZCZFSIUL, $\dagger$ \\ STEVEN D. MARLIN, $\uparrow$ AND MYRON LEVINE $\ddagger$
}

\begin{abstract}
* Unil for Laboralorry Animal Melicine, †Graduate Program in Cellular and Molecular Biology at Michigan, and $\ddagger$ Department of Human Genetics, University of Michigan Medical School, Ann Arbor, Michigan 48109
\end{abstract}

Received July 19, 1982; accepted November 17, 1982

\begin{abstract}
The surface membranes of cells infected with herpes simplex virus type 1 (HSV-1), strain KOS, contain three principal glyeoproteins, gC (apparent $M_{\mathrm{r}} 129 \mathrm{k}$ ), gB (apparent $M_{\mathrm{r}} 120 \mathrm{k}$ ), and $\mathrm{gD}$ (apparent $M_{\mathrm{r}} 58 \mathrm{k}$ ). Infections carried out in the presence of the glycosylation inhibitor 2-deoxy-D-glucose result in the loss of the mature species with the concurrent appearance of lower-molecular-weight polypeptides which are presumably partially glycosylated forms of the fully processed glycoproteins. Specific immunoprecipitation of radiolabeled cytoplasmic extracts of 2-deoxy-D-glucose-inhibited infections identified partially glycosylated proteins designated DG92, DG88, and DG53, which are antigenically related to the corresponding mature forms $\mathrm{gB}, \mathrm{gC}$, and $\mathrm{gD}$. Cell surface radioiodination, in combination with specific immunoprecipitation, revealed that DG88 and DG53 were the principal species transported to the cell surface in 2-deoxy-D-glucoseinhibited infections. DG92 was readily detected in the cytoplasm but not on the plasma membrane. Cells infected with the KOS mutant, syn LD70, did not synthesize glycoprotein gC. In glycosylation-inhibited syn LD70 infections, DG88 was not detected in either the cytoplasm or plasma membrane, demonstrating a genetic relationship between DG88 and gC. Polyclonal and monoclonal antibodies directed against the glycoproteins $\mathrm{gC}, \mathrm{gB}$, and gD sensitized infected cells to complement-mediated immune cytolysis. Cells infected in the presence of the inhibitor were sensitized to lysis only by antibody specific for $\mathrm{gC}$ and gD. The glycosylation-inhibited cells were insensitive to immunolysis by anti-gB monoclonal antibody. These findings confirm that the glycosylation-deficient forms of $\mathrm{gC}$ and $\mathrm{gD}$, but not $\mathrm{gB}$ reach the cell surface in the presence of inhibitor and that the inhibitorinduced alterations in glycosylation do not cause a complete loss of antigenicity. Inoculation of mice with syngeneic 3T3 cells infected in the presence or absence of inhibitorinduced cytolytic and neutralizing antibody. A major portion of the cytolytic antibody was directed against $\mathrm{gC}$, but anti-gC antibody appeared to play a minor role in virus neutralization. While the serum induced by the control infected cells contained precipitating antibodies for $\mathrm{gC}, \mathrm{gB}$, and $\mathrm{gD}$, the serum derived from mice inoculated with inhibitor-treated infected cells had only weak immunoprecipitating activity against $g B$. Together, these findings have identified partially glycosylated forms of the major HSV glycoproteins and show that complete glycosylation is not required for transport of some of these partially glycosylated polypeptides to the cell surface. Moreover, complete glycosylation of the glycopeptides is not essential for maintenance of antigenicity or immunogenicity, indicating that at least some determinants recognized by antibodies directed against the mature glycoproteins are not affected by 2-deoxy-D-glucose-induced carbohydrate alterations.
\end{abstract}

\footnotetext{
${ }^{1}$ Present address: Institut für Virusforschung, Im Neuenheimer Feld 280, D-6900 Heidelberg 1, West Germany. To whom reprint requests should be addressed.
}

\section{INTRODUCTION}

Herpes simplex virus (HSV) encodes at least four antigenically distinct glycopeptides designated $\mathrm{gC}, \mathrm{gA} / \mathrm{gB}, \mathrm{gE}$, and $\mathrm{gD}$ 
with corresponding apparent $M_{\mathrm{r}}$ of $129 \mathrm{k}$, $126 \mathrm{k}, 80 \mathrm{k}$, and 58k (Spear, 1976; Baucke and Spear, 1979; Eisenberg et al., 1979). Glycoproteins $\mathrm{gB}$ and $\mathrm{gD}$ appear to be of the delayed early class, while gC may be of the late class of viral structural polypeptides synthesized in the course of infection (Honess and Roizman, 1974; Cohen et al., 1980; Marsden et al., 1976; Marsden et al., 1978; Peake et al., 1982; Balachandran et al., 1982). Although initial studies indicated that $\mathrm{gA}$ and $\mathrm{gB}$ were antigenically distinct and separate gene products (Spear, 1976), recent evidence suggests that $\mathrm{gA}$ and $\mathrm{gB}$ are different forms of the same polypeptide (Eberle and Courtney, 1980a; Person et al., 1982; Pereira et al., 1982). The HSV glycoproteins are transported to the surface membrane of infected cells early in the replication cycle, with maximum levels of accumulation occurring concurrently with the release of active virus (Glorioso and Smith, 1977; Norrild et al., 1978, 1980). The HSV glycoproteins become incorporated into the virion envelope (Spear and Roizman, 1972; Sarmiento et al., 1979) during the process of budding. Morphological evidence indicates that budding occurs at the inner lamella of the nuclear membrane (Morgan et al., 1959; Nii et al., 1968).

The processing and intracellular transport of the HSV glycoproteins are still poorly understood. It is clear, however, that the glycoproteins are glycosylated through a series of successive intermediate stages detected by changes in apparent molecular weights in pulse-chase experiments (Honess and Roizman, 1975; Spear, 1976; Cohen et al., 1980). Glycoprotein-specific antisera have been used to detect at least one partially glycosylated intermediate for each major glycoprotein species (Spear, 1976; Eisenberg et al., 1979; Eberle and Courtney, 1980b). Based on studies of vesicular stomatitis virus (VSV) and Sindbis virus glycoprotein processing and intracellular transport (Hunt et al., 1978; Katz et al., 1977; Knipe et al., 1977; Lodish et al., 1980; Rothman et al., 1980a, b), it might be assumed that the HSV glycoprotein messenger RNAs are translated on membranebound polysomes and that a mannose-rich oligosaccharide core becomes covalently attached to specific asparagine residues by rough endoplasmic reticulum-associated glycosyl transferases as a cotranslational event. Pizer et al. (1980) have provided evidence for $\mathrm{N}$-linked mannose core glycosylation of glycoprotein gD. Further, carbohydrate branch chain elongation by sequential addition of $N$-acetylglucosamine, galatose, fucose, and sialic acid presumably occurs following transport of the glycoproteins to the Golgi in clathrin-coated vesicles as is the case for VSV glycoprotein G (Tabas et al., 1979; Rothman and Fine, $1980 \mathrm{a}, \mathrm{b})$. The mature glycoproteins are finally inserted into the cell surface and possibly other membranes. It seems unlikely that fully mature species are transported to the nuclear membrane, since the mature glycoproteins have not been detected in the nuclei of infected cells (Holland, 1978). In addition to N-linked oligosaccharides (Peake et al., 1982), evidence is accumulating that at least one HSV glycoprotein, $\mathrm{gC}$, is unique in that it contains both $\mathrm{N}$-linked sugars and $\mathrm{O}$-linked oligosaccharides (Olofsson et al., 1981a). In this regard, $\mathrm{gC}$ has been shown to combine with Helix pomatia lectin indicating the presence of an unusual sugar, $N$-acetylgalactosamine, which has been associated with O-linked branch chains in other viral glycoproteins (Olofsson et al., 1981b). These findings raise the possibility that the HSV glycoproteins may be processed along more than one intracellular pathway.

Glycosylation inhibitors have been used as an approach to identify partially glycosylated forms of the HSV glycoproteins and to detect differences in the intracellular movement and location of the druginduced intermediates (Campadelli-Fiume et al., 1980; Courtney, 1976; Knowles and Person, 1976; Pizer et al., 1980; Peake et al., 1982; Johnson and Spear, 1982; Norrild and Pedersen, 1982). Cells infected in the presence of the sugar analog of mannose, 2deoxy-D-glucose, synthesize partially glycosylated forms of the virus-specified glycoproteins (Courtney, 1976; Knowles and Person, 1976). Although virions are produced under these conditions, they are not infectious (Courtney, 1976). Other viriondirected cell surface changes, including cell 
fusion, are also inhibited (Knowles and Person, 1976). Courtney et al. (1973) reported that 2-deoxy-D-glucose is incorporated into the underglycosylated forms of the glycoproteins as a substitute for mannose, preventing the addition of the complete mannose core and oligosaccharide chain elongation. Tunicamycin inhibits glycosylation of HSV glycoproteins by acting as an analog of UDP- $N$-acetyl glucosamine (Pizer et al., 1980). This drug disrupts cotranslational glycosylation of the peptide backbone by interfering with formation of the dolicol pyrophosphate- $N$ acetyl glucosamine intermediate that normally acts as a carrier for $N$-glycosidic linkage of core oligosaccharides to asparagine residues (Struck and Lennarz, 1977; Waechter and Lennarz, 1976). Norrild and Pedersen (1982) recently reported that cells infected in the presence of tunicamycin contain one underglycosylated form of glycoprotein $\mathrm{gC}$ in the plasma membrane, a finding not confirmed by Peake et al. (1982). Cell fusion by syncytial forming mutants of $\mathrm{HSV}$ is also inhibited (Pizer et $a l ., 1980)$. Compadelli-Fiume et al. (1980) reported that the glycosylation inhibitor benhydrazone caused the accumulation of a glycoprotein intermediate with an apparent molecular weight identical to $\mathrm{gA}$ with the concomitant loss of $\mathrm{gB}$. Again, no infectious virus or virus-induced cell fusion occurred in the presence of this inhibitor. Inhibitors of Golgi functions such as monensin prevent Golgi-associated oligosaccharide chain elongation, but not core glycosylation associated with the rough endoplasmic reticulum (Tartakoff and Vassalli, 1977, 1978). Monensin treatment reduces but does not prevent the production of infectious enveloped virus (Johnson and Spear, 1982), suggesting that core glycosylation is sufficient for the production of functional glycoproteins.

Our laboratory has been studying the contribution of the carbohydrate portion of the HSV glycoproteins to glycopeptide processing, transport, and antigenicity. In this report, we describe the effects of the glycosylation inhibitor 2-deoxy-D-glucose on the transport of partially glycosylated forms of the HSV glycoproteins to the cell surface membrane and on the ability of these forms to retain antibody combining sites. Partially glycosylated forms antigenically related to mature glycoprotein species $\mathrm{gC}, \mathrm{gB}$, and $\mathrm{gD}$ were identified. The partially glycosylated forms of $\mathrm{gC}$ and $\mathrm{gD}$ were shown to combine with cytolytic antibody at the infected cell surface and sensitize the cell to complement-mediated cytolysis. The immunogenicity of the partially glycosylated glycoproteins was demonstrated by their ability to induce high titers of neutralizing and cytolytic antibody in mice immunized with syngeneic cells infected with HSV in the presence of 2-deoxy-D-glucose.

\section{MATERIALS AND METHODS}

Cells and virus. Human embryonic lung (HEL) and mouse 3T3 cells were grown and maintained in Eagle's minimum essential medium, MEM (GIBCO Laboratories, Grand Island, N. Y.), nonessential amino acids, and $10 \%$ heat-inactivated fetal calf serum (GIBCO). Wild-type HSV-1 (KOS) and mutant syn LD70 virus were grown in African green monkey kidney (Vero) cells and titered as plaque-forming units (PFU) by standard plaque assays in Vero cells (Glorioso et al., 1980). The syncytial mutant, syn LD70, was isolated from the KOS strain in this laboratory (SandriGoldin et al., 1981). Syn LD70 does not complement the mutant MP of HSV-1, strain $\mathrm{mP}$ (Sandri-Goldin et al., 1981; Ruyechan et al., 1979) and fails to synthesize glycoprotein C (see Results).

Antisera. HSV-1 (KOS) rabbit antisera were obtained by intramuscular injection of New Zealand White rabbits with KOSinfected primary rabbit kidney cells (uvinactivated) in complete Freund's adjuvant (GIBCO), as described previously (Smith and Glorioso, 1976). Also used in these studies were three rabbit antisera monospecific for the individual HSV-1 glycoproteins $\mathrm{gC}, \mathrm{gB}$, and $\mathrm{gD}$. Antisera specific for $\mathrm{gC}$ and $\mathrm{gB}$ were kindly provided by Dr. Richard Courtney, and the gD specific serum by Dr. Gary Cohen. All antisera neutralized HSV-1 (KOS) in the presence of rabbit complement.

Mouse antisera directed against HSV-1 
were produced in 100- to 200-day-old BALB/c mice (Charles River Breeding Laboratories, Wilmington, Mass.) against both live virus and virus-infected syngeneic cells (uv-inactivated). For production of antisera against live virus, ten mice were each infected by intraperitoneal injection of $2 \times 10^{7} \mathrm{PFU}$, a sublethal dose which all animals survived. For production of antisera against cells infected with wild-type HSV-1 (KOS), 3T3 cells were infected at an m.o.i. of 10 and harvested at $18 \mathrm{hr}$ postinfection. 3T3 cells infected in the presence of $10 \mathrm{mM}$ 2-deoxy-D-glucose (Sigma Chemical Co., St. Louis, Mo.) were also used as immunogens. The infected cells were washed twice in Dulbecco's phosphatebuffered saline (PBS), $\mathrm{pH} 7.0$, and a $1-\mathrm{ml}$ suspension of cells was uv-irradiated in an open $60-\mathrm{mm}^{2}$ petri dish on a rotary shaker for $20 \mathrm{~min}$ at a distance of $10 \mathrm{~cm}$ using a uv light source (Westinghouse Sterilamp, Type WL-15). Groups of 10 mice were injected intraperitoneally with $10^{7}$ infected cells in $0.5 \mathrm{ml}$ complete Freund's adjuvant. The groups of mice were bled retroorbitally on Day 15 postinoculation. Sera were pooled and stored at $-70^{\circ} \mathrm{C}$. Samples were heat inactivated prior to use. Monoclonal antibodies C3, B1, and D1 directed against HSV-1 glycoproteins $\mathrm{gC}, \mathrm{gB}$, and $\mathrm{gD}$, respectively, were produced and characterized as described by Holland et al. (1982).

Inhibition of glycosylation with 2-deoxy$D$-glucose. After $1 \mathrm{hr}$ for adsorption, infected cell monolayers were overlayed with medium containing $10 \mathrm{~m} M 2$-deoxy-D-glucose. The inhibitors were present for the duration of the infection.

Radioiodination of viral cell surface antigens, intrinsic radiolabeling of viral proteins, and immunoprecipitation of viral antigens. Virus-induced cell surface antigens were radiolabeled with ${ }^{125} \mathrm{I}$ as follows. Monolayers of $10^{7} \mathrm{HEL}$ cells were infected at a multiplicity of $10 \mathrm{PFU} /$ cell. At $18 \mathrm{hr}$ after infection, the medium was decanted and the monolayers washed twice with PBS and once with PBS plus $5 \mathrm{~m} M \beta$-D-glucose. Each monolayer received $1 \mathrm{ml}{ }^{125} \mathrm{I}$ (as NaI, Amersham/Searle, Arlington Heights, Ill.) at a concentration of $0.4 \mathrm{mCi} / \mathrm{ml}$ in $\mathrm{PBS}$ containing $5 \mathrm{~m} M \beta$-D-glucose, $0.1 \mathrm{ml}$ glucose oxidase $(0.25 \mathrm{mg} / \mathrm{ml}$, Worthington Biochem., Freehold, N. J.), and $0.1 \mathrm{ml} \mathrm{lac-}$ toperoxidase $(1 \mathrm{mg} / \mathrm{ml}$ in PBS, Sigma, St. Louis, Mo.). Monolayers were incubated at room temperature for $15 \mathrm{~min}$. The reaction was stopped by rinsing the monolayer once with PBS and twice with PBI (PBS with $20.55 \mathrm{~g} /$ liter $\mathrm{NaI}$ substituted for the $8 \mathrm{~g} /$ liter $\mathrm{NaCl}$ normally present in PBS).

Intrinsic radiolabeling of infected cell proteins was carried out as follows. HEL cell monolayers $\left(1 \times 10^{7}\right.$ cells $)$ were infected with virus at a multiplicity of 10 $\mathrm{PFU} /$ cell. After adsorption for $1 \mathrm{hr}$, the monolayer was overlaid with $5 \mathrm{ml}$ MEM plus $2 \%$ fetal calf serum and incubated at $37^{\circ} \mathrm{C}$. Four hours after infection, the medium was replaced with $5 \mathrm{ml}$ MEM containing either $2 \mu \mathrm{Ci} / \mathrm{ml}\left[{ }^{14} \mathrm{C}\right]$ glucosamine, $2 \mu \mathrm{Ci} / \mathrm{ml}\left[{ }^{3} \mathrm{H}\right]$ mannose, or $5 \mu \mathrm{Ci} / \mathrm{ml}\left[{ }^{35} \mathrm{~S}\right]-$ methionine (Amersham/Searle). Twentyfour hours after infection, the medium was aspirated and $0.1 \mathrm{ml}$ lysis buffer (PBS, pH 7.4 , plus $1 \%$ Nonidet $P-40$, and $0.1 \mathrm{~m} M$ phenylmethylsulfonyl fluoride) containing $5 \mu \mathrm{g} / \mathrm{ml}$ micrococcal nuclease (Sigma) was added to the cells followed by incubation at $37^{\circ} \mathrm{C}$ for $15 \mathrm{~min}$. The lysate was mixed with $0.1 \mathrm{ml} 2 \times$ electrophoresis sample solution (ESS, 2\% sodium dodecyl sulfate (SDS), 5\% 2-mercaptoethanol, $10 \mathrm{~m} M$ Tris, $10 \%$ sucrose, $1 \mathrm{mg} / \mathrm{ml}$ bromophenol blue, $\mathrm{pH}$ 7.0) and the lysates stored at $-20^{\circ} \mathrm{C}$. Prior to SDS-polyacrylamide gel electrophoresis, samples were heated at $100^{\circ} \mathrm{C}$ for $2 \mathrm{~min}$.

For immunoprecipitation, radiolabeled monolayers of cells were scraped into PBS, pelleted, and disrupted by resuspension of the pellet in $1 \mathrm{ml}$ lysis buffer. Viscosity was decreased by addition of $50 \mu 1$ micrococcal nuclease $(0.1 \mathrm{mg} / \mathrm{ml}$, Sigma) followed by incubation at $37^{\circ} \mathrm{C}$ for $15 \mathrm{~min}$. Debris was removed by two successive centrifugations ( $2000 \mathrm{~g}$ for $15 \mathrm{~min}$ followed by $15,000 \mathrm{~g}$ for $15 \mathrm{~min}$ ). Viral antigens were complexed with antibody by the addition of $20 \mu \mathrm{l} \mathrm{HSV}-1$ (KOS) specific rabbit antiserum to the supernatant followed by incubation on ice for $1 \mathrm{hr}$. Antigen-antibody complexes were recovered by the addition 
of $0.2 \mathrm{ml} 40 \%(\mathrm{v} / \mathrm{v})$ protein A-Sepharose CL-4B beads (Pharmacia, Piscataway, N. J.) in lysis buffer plus $20 \%$ sucrose, followed by incubation on ice for $30 \mathrm{~min}$. The beads were washed three times with lysis buffer, resuspended in $100 \mu \mathrm{l} 2 \times$ ESS for a final protein concentration of approximately $1 \mathrm{mg} / \mathrm{ml}$, and frozen. Prior to SDSpolyacrylamide gel electrophoresis, the sample was heated to $100^{\circ} \mathrm{C}$ for 2 min and the beads were removed by centrifugation at $1000 \mathrm{~g}$ for $5 \mathrm{~min}$.

Polyacrylamide gel electrophoresis. Protein samples were analyzed by SDS-polyacrylamide gel electrophoresis using the buffer system of Laemmli (1970). Acrylamide gels $(10 \%)$ were crosslinked with $N, N^{\prime}$-diallyltartardiamide (Bio-Rad Laboratories, Richmond, Calif.) as described previously (Glorioso et al., 1980). Electrophoresis of 30- $\mu$ l samples was carried out at a constant current of $25 \mathrm{~mA} / \mathrm{gel}$. The gels were fixed in $10 \%$ methanol plus $7.5 \%$ acetic acid, then treated with $1.0 \mathrm{M}$ sodium salicylate in $0.1 \mathrm{M}$ Tris to provide fluorographic enhancement. Fluorographs of the dried gels were made on XR-5 film (Kodak, Rochester, N. Y.) exposed at $-70^{\circ} \mathrm{C}$. Estimation of molecular weights was made by the method of Weber and Osborn (1969), using a Pharmacia protein standards calibration kit.

${ }^{51} \mathrm{Cr}$-Release assay for immune cytolysis. Monolayers of HEL cells grown in $150-\mathrm{cm}^{2}$ flasks were infected with wild-type HSV1 (KOS) or mutant syn LD70 at an m.o.i. of 10 . After allowing the virus to absorb for $1 \mathrm{hr}$, the monolayer was rinsed with PBS and overlaid with $10 \mathrm{ml}$ MEM-2 plus $1 \mathrm{mCi}{ }^{51} \mathrm{Cr}$ (as sodium chromate; Amersham/Searle) with or without the addition of $10 \mathrm{~m} M 2$-deoxy-D-glucose. At $18 \mathrm{hr}$ postinfection, the cells were trypsinized and washed four times in MEM-2. The cells were resuspended at a concentration of $2 \times 10^{5}$ cells $/ \mathrm{ml}$ in MEM- 2 containing $10 \%$ normal rabbit serum as a complement source. Cells used in these experiments were always at least $95 \%$ viable as assayed by trypan blue dye exclusion. One-hundred microliters of cell suspension $\left(2 \times 10^{4}\right.$ cells) was added to three replicate wells of a 96- well plate followed by an equal volume of serially diluted antisera. The plates were incubated for $3 \mathrm{hr}$ at $37^{\circ} \mathrm{C}$. After incubation, the plates were centrifuged at $1000 \mathrm{~g}$ and ${ }^{51} \mathrm{Cr}$ release was measured by counting a 100- $\mu$ l sample of supernatant fluid from each well in a gamma counter. Controls for each experiment included wells incubated with normal mouse serum plus complement (minimum release) and counts made from wells treated with $100 \mu 11 N$ $\mathrm{HCl}$ (maximum release). The following formula was used to calculate the percentage specific ${ }^{51} \mathrm{Cr}$ release: percentage release $=($ mean test $\mathrm{cpm}-$ mean minimum cpm $) /($ mean maximum cpm - mean minimum $\mathrm{cpm}) \times 100$. The $50 \%$ endpoint titer was taken as the dilution giving onehalf maximum percentage ${ }^{51} \mathrm{Cr}$ release.

Virus neutralization. Mouse antisera were assayed for neutralization of $\mathrm{HSV}-1$ (KOS) in the presence and absence of complement. Doubling dilutions of antisera were carried out in 96-well microtiter plates (Linbro, Hamden, Conn.) such that the final volume was $50 \mu \mathrm{l}$ per well. Fifty microliters of MEM plus $2 \%$ fetal bovine serum (MEM-2) containing $10^{4}$ PFU KOS virus was added to each serum dilution and the plates were incubated at $37^{\circ} \mathrm{C}$ for $1 \mathrm{hr}$. In assays involving complement-enhanced neutralization, the virus was diluted in MEM-2 plus $20 \%$ normal rabbit serum as a complement source. Subsequently, $3 \times 10^{4}$ Vero cells in $100 \mu \mathrm{l}$ of MEM- 2 were added to each test well and cells were allowed to attach by further incubation at $37^{\circ} \mathrm{C}$ for $48 \mathrm{hr}$. After incubation, wells containing active virus showed cytopathic effect, whereas uninfected cells appeared as normal monolayers. The wells were rinsed once with PBS and the cell monolayers stained with $1 \%$ crystal violet in $50 \%$ ethanol. The neutralization titer was expressed as the last dilution of antibody that inhibited cytopathic effect by at least $50 \%$. Cell controls consisted of wells in which only Vero cells were added with and without antiserum, and virus controls consisted of Vero cells plus virus without antiserum. Similar controls were performed in the presence of complement. 


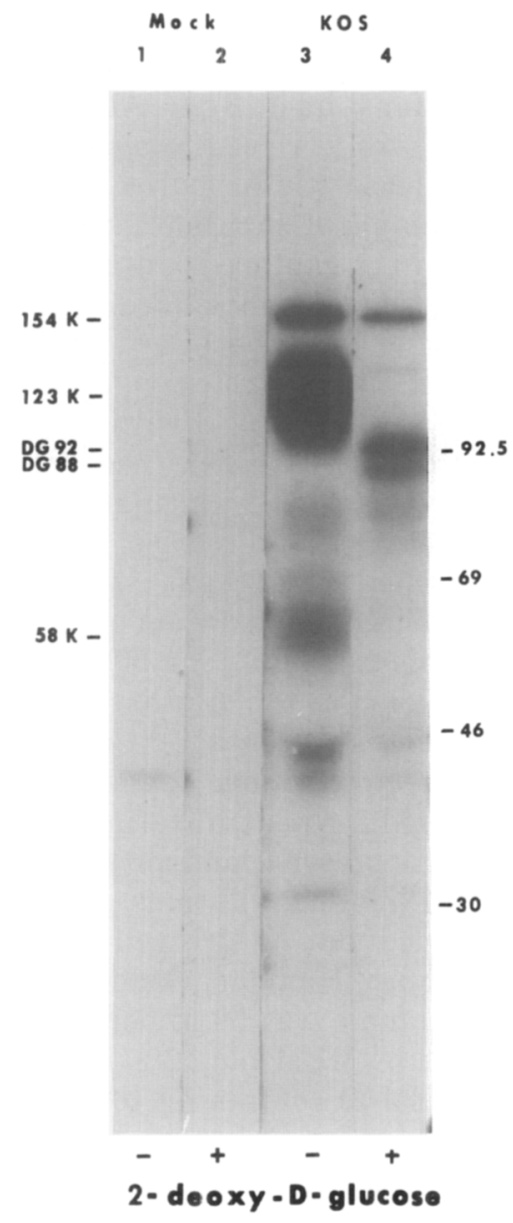

FIG. 1. Immunoprecipitation of HSV-1 proteins from cells infected in the presence and absence of 2-deoxyD-glucose. HEL cells were infected with wild-type virus or mock infected in the presence $(+)$ or absence (-) of $10 \mathrm{mM}$ 2-deoxy-D-glucose and were radiolabeled with [ ${ }^{35} \mathrm{~S}$ ]methionine from 4 to $24 \mathrm{hr}$ after infection. Viral proteins from infected cell lysates were immunoprecipitated with HSV-1 (KOS) specific rabbit antibody. Immunoprecipitated proteins were electrophoresed in 10\% SDS-polyacrylamide gels and the proteins were visualized by fluorography. Molecular weights $\left(\times 10^{-3}\right)$ are shown on the right.

\section{RESULTS}

Effect of 2-Deoxy-D-Glucose on the Maturation of Viral Glycoproteins and Their Transporl to the Cell Surface

The mature forms of the glycoproteins are not synthesized in cells infected with HSV-1 in the presence of 2-deoxy-D-glucose (Courtney, 1976; Knowles and Person, 1976). Rather, lower-molecular-weight protein species are observed. However, their relationship to the mature glycoproteins has not yet been determined. We initiated experiments to confirm earlier findings and to examine the antigenic relationships between these polypeptides and the mature virus-specified glycoproteins.

HEL cells infected with HSV-1 (KOS) in the presence and absence of 2-deoxy-Dglucose were metabolically radiolabeled with $\left.{ }^{35} \mathrm{~S}\right]$ methionine and viral antigens were immunoprecipitated from extracts of these infected cells with hyperimmune rabbit anti-HSV-1 specific antibody. The immunoprecipitates were electrophoresed in polyacrylamide gels and the resulting autoradiogram profiles are shown in Fig. 1. In the absence of inhibition, the major glycoprotein region, containing $\mathrm{gC}$ and $\mathrm{gA} /$ gB (average apparent $M_{\mathrm{r}} 123 \mathrm{k}$ ) was detected, as well as a protein band having an apparent $M_{\mathrm{r}}$ comparable to $\mathrm{gD}(58 \mathrm{k})$ (lane 3). The major capsid protein, ICP 154 (Heine et al., 1974; Spear and Roizman, 1972), also was precipitated. This result is typical of that found with hyperimmune rabbit antisera (J. Glorioso, unpublished observations). In the presence of 2-deoxyD-glucose (lane 4), the $123 \mathrm{k}$ and the $58 \mathrm{k}$ bands disappeared with the concomitant appearance of two new bands, a 92k and an $88 \mathrm{k}$ species. ICP 154 was again immunoprecipitated from lysates of inhibitortreated cells, but its apparent molecular weight remained unchanged as it is not a glycosylated protein. Mock-infected cells were almost completely unreactive with the rabbit antiserum (Fig. 2, lanes 1 and 2 ), supporting the presumption that the protein bands immunoprecipitated from virus-infected cells were virus specified. Comparable results also were achieved using mouse antisera against HSV-1-infected syngeneic cells or against live virus.

A broad radiolabeled band migrating with the $92 \mathrm{k}$ and $88 \mathrm{k}$ protein species could be detected in extracts of cells infected in the presence of radiolabeled $\left[{ }^{14} \mathrm{C}\right] \mathrm{glu}$ cosamine but not $\left[{ }^{3} \mathrm{H}\right]$ mannose (data not shown). This demonstrated that one or both of these peptide bands are partially glycosylated and are presumably devoid of 


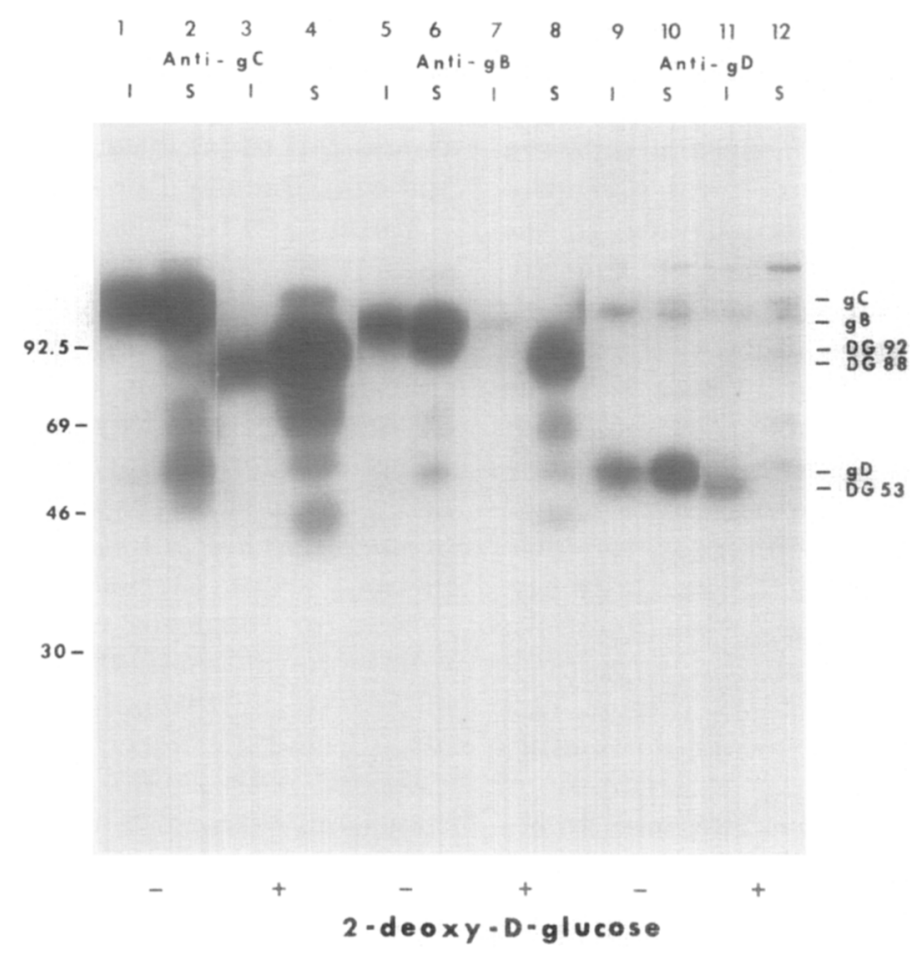

FIG. 2. Comparison of $\left[{ }^{35} \mathrm{~S}\right]$ methionine and ${ }^{125} \mathrm{I}$-labeled proteins immunoprecipitated from cells infected in the presence and absence of 2-deoxy-D-glucose with monospecific antisera. HEL cells were infected with wild-type virus in the presence $(+)$ and absence $(-)$ of 2-deoxy-D-glucose, and were radiolabeled with $\left[{ }^{35} \mathrm{~S}\right]$ methionine from 4 to $24 \mathrm{hr}$ after infection, or radioiodinated at $18 \mathrm{hr}$ after infection. Viral proteins from infected cell lysates were immunoprecipitated with polyclonal rabbit antisera monospecific for $\mathrm{gC}$ (lanes 1-4), $\mathrm{gB}$ (lanes 5-8), and $\mathrm{gD}$ (lanes 9-12). Immunoprecipitates were electrophoresed in $10 \%$ SDS-polyacrylamide gels and the proteins were visualized by fluorography. I and $S$ above the lanes represent ${ }^{125} \mathrm{I}$ or $\left[{ }^{35} \mathrm{~S}\right]$ methionine labeling, respectively. Molecular weights $\left(\times 10^{-3}\right)$ are indicated on the left.

the mannose core. These are, thus, good candidates for polypeptides related to the fully processed glycoproteins. The nomenclature, DG, followed by the apparent molecular weight will be used to designate altered proteins synthesized in 2-deoxy-Dglucose-inhibited cells.

Monospecific polyclonal rabbit antisera reactive with the individual $\mathrm{HSV}-2$ glycoproteins were used to examine the antigenic relatedness of the $D G$ proteins to the mature glycoproteins. Monospecific anti-gC (Fig. 2, lane 2), anti-gB (Fig. 2, lane 6), and anti-gD (Fig. 2, lane 10) precipitated the corresponding mature antigens from $\left[{ }^{35} \mathrm{~S}\right]$ methionine-labeled KOS-infected cells in the absence of 2deoxy-D-glucose. In presence of the inhibitor, anti-gC serum precipitated the DG88 polypeptide (Fig. 2, lane 4), demonstrating its antigenic relatedness to gC. Monospecific anti-B antiserum precipitated the DG92 protein from the $\left[{ }^{35} \mathrm{~S}\right]$ methionine-labeled extracts inhibited with 2-deoxy-Dglucose (Fig. 2, lane 8), confirming that this protein is antigenically related to $\mathrm{gB}$. However, anti-gD failed to precipitate any polypeptide in the molecular size range expected for glycoprotein $\mathrm{gD}$ from extracts of $\left[{ }^{35} \mathrm{~S}\right]$ methionine labeled glycosylationinhibited infected cells (Fig. 2, lane 12). The appearance of multiple bands in the $\left[{ }^{35} \mathrm{~S}\right]$ methionine lanes require some comment. These bands are only observed in autoradiograms of overexposed gels. They could be glycoprotein precursors and/or degradation products of the mature or partially processed glycoproteins. 
Cells infected under the same conditions were subjected to cell surface radioiodination followed by immunoprecipitation of extracts with the monospecific antisera to detect the presence of viral glycoproteins on the infected cell surface. In the absence of 2-deoxy-D-glucose, the radioiodinated glycoproteins $\mathrm{gC}, \mathrm{gB}$, and $\mathrm{gD}$ were readily precipitated by the corresponding antisera (Fig. 2, lanes 1, 5, and 9 , respectively). The apparent molecular weight of the corresponding ${ }^{125} \mathrm{I}-$ and $\left[{ }^{35} \mathrm{~S}\right]-$ methionine-labeled proteins were identical. In the presence of inhibitor, the antigC serum precipitated the partially glycosylated $88 \mathrm{k}$ form (Fig. 2, lane 3) and the anti-gD serum precipitated a polypeptide with an apparent $M_{\mathrm{r}}$ of 53k (Fig. 2, lane 11) from the cell surface. These findings confirmed the antigenic relatedness of DG88 to gC (130k) and established an antigenic relationship between DG53 and gD (58k). Very little fully processed $\mathrm{gB}$ and no DG92, the partially glycosylated form of gB, were observed on immunoprecipitation of radioiodinated polypeptides with the anti-gB serum. This was the case despite the fact that these gels were intentionally overexposed to increase the chances of detecting low amounts of DG92 and that an ample supply of DG92 was available in the cytoplasm of the inhibited cells (Fig. 2, lane 8).

Mouse monoclonal antibodies (Holland et al., 1982) specific for the three HSV-1 glycoproteins $\mathrm{gC}, \mathrm{gB}$, and $\mathrm{gD}$ also were used to immunoprecipitate these antigens from extracts of radioiodinated cells infected in the presence and absence of inhibitor (data not shown). The results were comparable to those obtained with the polyclonal rabbit sera, again demonstrating that DG88, DG92, and DG53 were antigenically related to the mature glycoproteins $\mathrm{gC}, \mathrm{gB}$, and $\mathrm{gD}$, respectively. Again only DG88 and DG53 were observed on the surface of cells infected in the presence of inhibitor.

\section{Confirmation of the DG88-gC Relationship Using a gC-Negutive HSV-1 Mutant}

We sought to confirm a genetic relationship, not just the antigenic related- ness of DG88 with $\mathrm{gC}$, through use of the gC-deficient mutant, syn LD70. In this case, cells infected in the presence of inhibitor should fail to produce the polypeptide $\mathrm{gC}$ and consequently fail to produce DG88.

Mutant syn LD70 is a syncytial forming mutant of strain KOS that fails to compliment the syncytial mutant $M P$ of $\mathrm{HSV}$ $1(\mathrm{mP})$, suggesting they both sustain a lesion in a locus, $\mathrm{Cr}$, thought to control expression of gC (Ruyechan et al., 1979). Infections were performed in the presence and absence of 2-deoxy-D-glucose with the gC-negative mutant syn LD70. Similar infections were carried out with HSV-1 (KOS) for purposes of comparison. The cells were radioiodinated for the detection of viral cell surface antigens. The antigens $\mathrm{gC}, \mathrm{gB}$, and $\mathrm{gD}$ were readily immunoprecipitated with rabbit anti-HSV-1 antiserum from extracts of radioiodinated KOS infected cells (Fig. 3, lane 1), while only $\mathrm{gB}$ and $\mathrm{gD}$ were immunoprecipitated from syn LD70 infections (lane 7). The phenotype of the syn LD70 mutant is failure to synthesize the $\mathrm{gC}$ protein. Infections were then performed in the presence of 2-deoxyD-glucose with wild-type virus and the $\mathrm{gC}$ negative mutant syn LD70. In the presence of inhibitor, both anti-HSV-1 and rabbit anti-gC antisera immunoprecipitated DG88 from KOS-infected cell extracts (Fig. 3 , lanes 2 and 6 , respectively). Most telling was the complete absence of the DG88 protein in syn LD70 extracts (lanes 8 and 12). That is, cells infected with a mutant which fails to express $\mathrm{gC}$ also did not produce DG88. The data establish not only an antigenic, but a genetic relationship between $\mathrm{gC}$ and the glycosylation-inhibited protein, DG88. The absence of an underglycosylated form of $\mathrm{gB}$ on the cell surface was also evident in glycosylation inhibited $\mathrm{KOS}$ and in syn LD70 infections.

\section{Immune Cytolysis of Target Cells Infected in the Presence of 2-deoxy-D-glucose}

Having established that both rabbit and mouse antisera can immunoprecipitate the mature and glycosylation-inhibited forms of the HSV-1-induced glycoproteins, ex- 


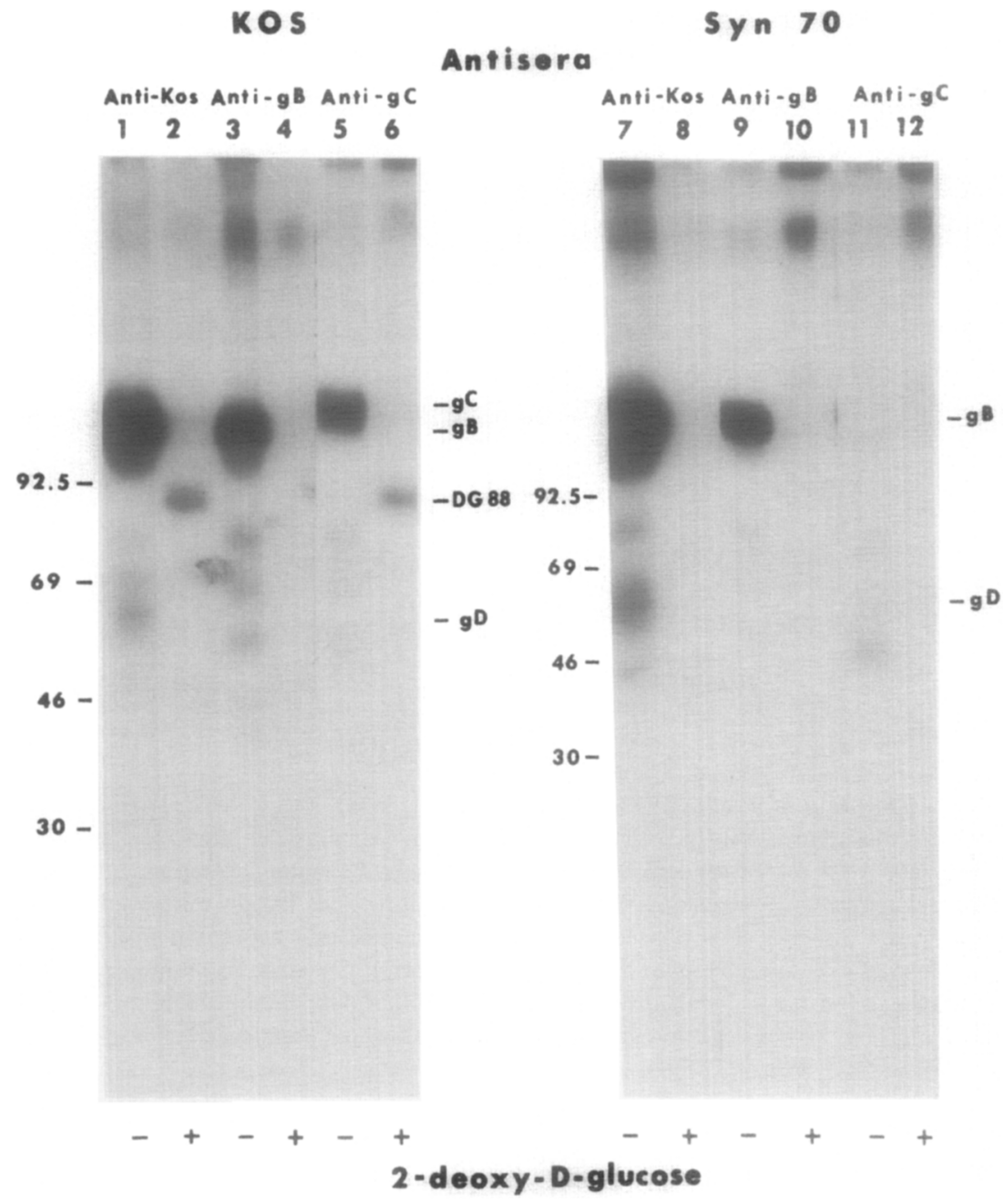

Fig. 3. Effect of 2-deoxy-D-glucose on cell surface glycoproteins of wild-type HSV-1 (KOS)- and mutant syn LD70-infected cells. IIEL cells were infected with wild-type and mutant syn LD70 virus, treated in the presence of 2 -deoxy-D-glucose, surface labeled with ${ }^{125} \mathrm{I}$, and immunoprecipitated with polyclonal rabbit antibodies monospecific for individual glycoproteins, as described in Fig. 2. Molecular weights $\left(\times 10^{-3}\right)$ are shown to the left of the fluorographs.

periments were undertaken to determine if these proteins are available on the infected cell surface as target antigens for cytolytic antibody.

The susceptibility of wild-type infected HEL target cells to immune cytolysis was examined using polyclonal antiserum derived from mice inoculated with wild-type KOS live virus. That this serum had a high cytolytic titer against both normal and 2deoxy-D-glucose-inhibited infected cells can be seen from the shapes of the serum dilution ${ }^{51} \mathrm{Cr}$-release curves in Fig. $4 \mathrm{~A}$ and the 50\% endpoint titers given in Table 1. High levels of cytolysis were achieved over many serum dilutions. The $50 \%$ endpoint of this antiserum against uninhibited KOSinfected target cells was 10240 , while the same cells infected in the presence of 2deoxy-D-glucose were only slightly less susceptible to cytolysis, the $50 \%$ endpoint was 6303 . These data demonstrate that the antigens which reach the cell surface in the glycosylation-inhibited cells are available to antibody and are reactive as targets for immune cytolysis. 


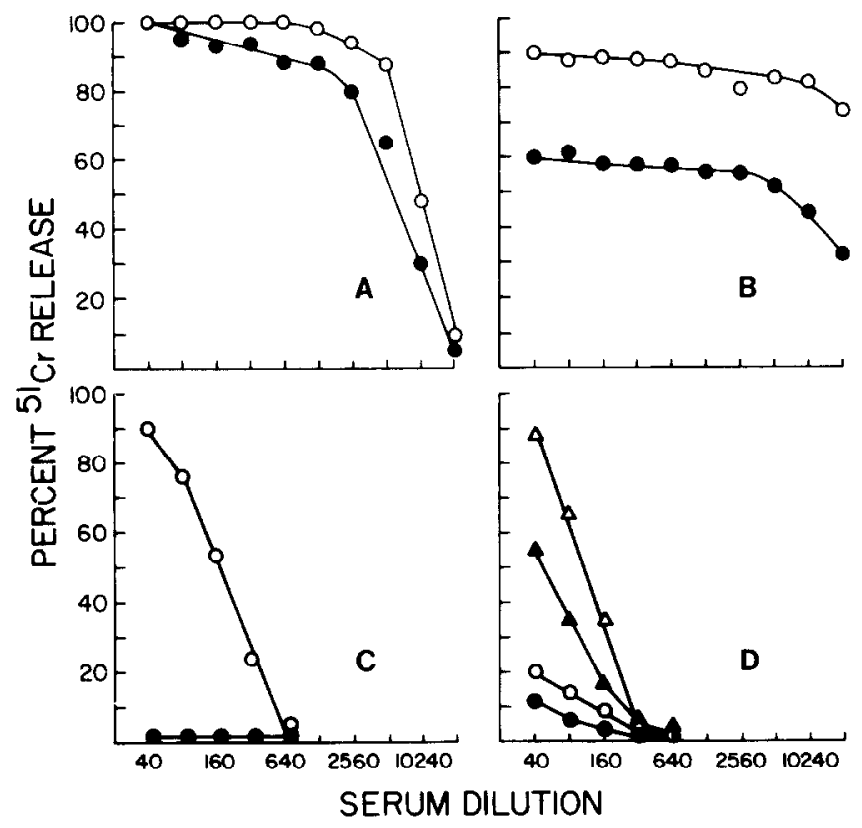

FIC. 4. Susceptibility of wild-type KOS-infected cells treated with 2-deoxy-D-glucose to complement-mediated immune cytolysis. HEL cells infected in the presence and absence of $10 \mathrm{mM}$ 2deoxy-D-glucose were tested for susceptibility to antibody dependent, complement-mediated immune cytolysis using ${ }^{51} \mathrm{Cr}$-release assays at $18 \mathrm{hr}$ after infection. Target cells used were 2-deoxyD-glucose-treated infected cells (closed circles and triangles) and untreated infected cells (open circles and triangles). Antisera used were mouse antiserum prepared by immunization with live virus (A), gC-specific monoclonal antibody (B), gB-specific monoclonal antibody (C), gD-specific monoclonal antibody ( $\mathrm{D}$, circles), and mouse polyclonal antiserum monospecific for $\mathrm{gD}(\mathrm{D}$, triangles).

The role played by the individual glycoproteins in immune cytolysis can be deduced by using the monoclonal antibodies in cytolysis reactions. Monoclonal anti-gC antibody was highly cytolytic for uninhibited infected cells, killing $90 \%$ of target cells (Fig. 4B), and gave a $50 \%$ endpoint of 20480 . The inhibited target cells were susceptible to cytolysis with anti-gC serum, although the maximum percentage ${ }^{51} \mathrm{Cr}$ release was only $60 \%$ (Fig. $4 \mathrm{~B}$ ). The dilution killing curve for inhibited cells paralleled that of uninhibited cells and gave a $50 \%$ cndpoint of 5881 . These results imply that DG88, the partially glycosylated form of $\mathrm{gC}$, was present on the cell surface and provided a good target for cytolytic antibody. A lower density of DG88 on the cell surface compared with the mature form of $\mathrm{gC}$ may be responsible for the $60 \%$ ${ }^{51} \mathrm{Cr}$ release in the inhibited target cells. Some $90 \%$ of uninhibited target cells were lysed by monoclonal anti-gB serum, giving a 50\% endpoint of 149 (Fig. 4C, Table 1), showing that the interaction of the gBspecific antibody with gB on the cell surface provides an efficient mechanism for complement fixation and cell destruction. However, target cells infected in the presence of 2-deoxy-D-glucose were completely resistant to immune cytolysis with this antiserum. These findings are taken as confirming the absence of detectable quantities of DG92, the gB-related polypeptide, on the cell surface of glycosylation-inhibited cells (Fig. 2, lane 7, and Fig. 3, lane 4). The monoclonal anti-gD serum showed a significant but poor killing reaction against both target cells (Fig. 4D, Table 1). That $\mathrm{gD}$-related polypeptides are present on the cell surface and available as targets for immunolysis was confirmed with rabbit polyclonal monospecific antigD antibody. Uninhibited and inhibited 
TABLE 1

Immune Cytolysis of TaRget Cells

\begin{tabular}{ccr}
\hline & \multicolumn{2}{c}{$\begin{array}{c}{ }^{51} \text { Cr-labeled KOS infected } \\
\text { target cells }\end{array}$} \\
\cline { 2 - 3 } & $\begin{array}{c}\text { Minus 2-deoxy- } \\
\text { D-glucose }\end{array}$ & $\begin{array}{c}\text { Plus 2-deoxy- } \\
\text { D-glucose }\end{array}$ \\
\hline Antiserum & & \\
Polyclonal & 10240 & 6303 \\
Anti-KOS & & \\
Monoclonal & 20480 & 5881 \\
Anti-gC & 149 & 0 \\
Anti-gB & 40 & 40 \\
Anti-gD & & \\
\hline
\end{tabular}

Note. The data presented are the $50 \%$ endpoint titrations of polyclonal and monoclonal cytolytic antibody directed against HSV-1 glycoproteins when tested against HSV-1 (KOS)-infected HEL target cells in the presence and absence of 2-deoxy-D-glucose.

target cells gave good killing curves (Fig. 4D) and 50\% endpoints of 106 and 57, respectively, with this serum.

\section{Immunogenicity of the Partially Glycosy- lated Forms of the HSV-1 Glycopro- teins}

The question arises as to whether 2deoxy-D-glucose treatment alters the immunogenicity of the glycoproteins, that is, whether the alterations in glycosylation affect the induction of cytolytic or virusneutralizing antibodies. BALB/c mice were immunized with syngeneic $3 \mathrm{~T} 3$ cells infected with wild-type virus in the presence and absence of 2-deoxy-D-glucose. The infected cells were treated with ultraviolet irradiation to inactivate virus before inoculation. The antisera were collected 15 days after inoculation and used in immune cytolysis and virus neutralization assays.

As an immunogen, 3T3 cells infected with KOS virions in the presence of 2deoxy-D-glucose gave a substantial but somewhat weaker cytolytic antibody titer than that induced with uninhibited cells (Fig. 5A, B; Table 2); $50 \%$ endpoints of 844 vs 3880 . How significant these differences in titer are is difficult to evaluate. It should be pointed out that 2-deoxy-D-glucose treatment has an inhibitory effect on overall protein synthesis (unpublished observations) in addition to its selective effect on glycosylation. Smaller amounts of antigen may have been available in the inhibited cells.

Some idea of the specificities of these antisera for the individual glycoproteins can be obtained using appropriate target cells in immune cytolysis assays. Mutant syn LD70 infected cells fail to synthesize $\mathrm{gC}$, leaving $\mathrm{gB}$ and $\mathrm{gD}$ on the infected cell surface. Glycoprotein $\mathrm{gB}$ is not available for interaction with cytolytic antibody on 2-deoxy-D-glucose-inhibited KOS-infected cells, leaving the immature forms of $\mathrm{gC}$ and $\mathrm{gD}$ on the cell surface. The underglycosylated forms of $\mathrm{gD}$ are the only de-

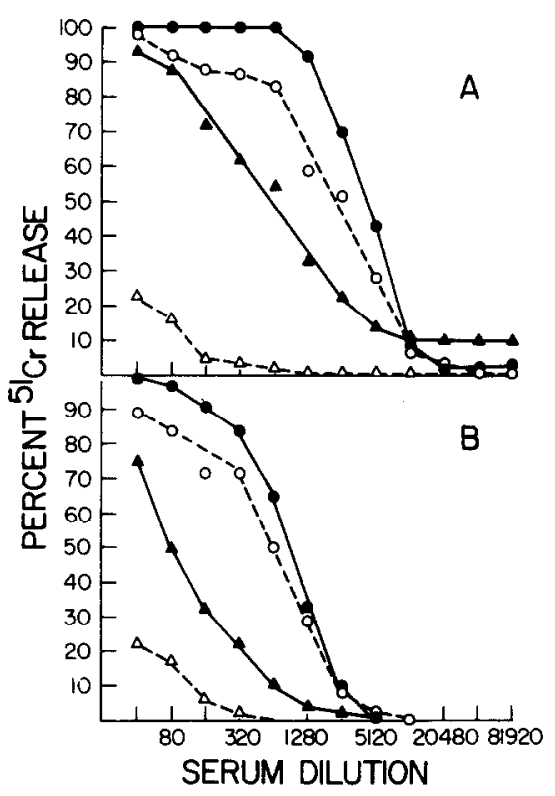

FIG. 5. Cytotoxic antibody activity of antisera prepared against 2-deoxy-D-glucose-treated and untreated HSV-1 (KOS)-infected cells. Antisera were produced in mice by immunization with uv-irradiated syngeneic 3T3 cells infected with wild-type virus in the presence and absence of $10 \mathrm{~m} M$ 2-deoxy-D-glucöse. Antisera produced against untreated infected cells (A) and treated infected cells (B) were tested against the following target cells using ${ }^{51} \mathrm{Cr}$-release assays: KOS-infected cells (๑), 2-deoxy-D-glucosetreated KOS-infected cells (O), mutant syn LD70-infected cells $(\Delta)$, and 2-deoxy-D-glucose-treated mutant sym LD70-infected cells $(\triangle)$. 
TABLE 2

IMMUNOGENICITY OF 2-DEOXY-D-GLUCOSE INHIBITED INFECTED CELLS

\begin{tabular}{|c|c|c|c|c|c|c|c|c|}
\hline \multirow[b]{4}{*}{ Antiserum } & \multirow{2}{*}{\multicolumn{4}{|c|}{${ }^{51} \mathrm{Cr}$-Labeled target cells }} & \multicolumn{4}{|c|}{ Virus target } \\
\hline & & & & & \multicolumn{2}{|c|}{ KOS } & \multicolumn{2}{|c|}{ SynLD70 } \\
\hline & \multicolumn{2}{|c|}{$-\mathrm{DG}$} & \multicolumn{2}{|c|}{$+\mathrm{DG}$} & \multicolumn{4}{|c|}{ Complement } \\
\hline & KOS & SynLD70 & KOS & SymLD70 & - & + & - & + \\
\hline KOS & 3880 & 557 & 2229 & 40 & 80 & 2560 & 160 & 2560 \\
\hline KOS + 2-deoxy-D-glucose & 844 & 80 & 640 & 40 & 40 & 1280 & 40 & 1280 \\
\hline
\end{tabular}

Note. The data presented are $50 \%$ endpoint titrations of cytolytic and neutralizing antibody contained in the BALB/c mouse antisera produced against syngeneic 3T3 cells infected with HSV-1 (KOS) or Syn LD ro both in the presence and absence of 2-deoxy-D-glucose.

tectable glycoproteins on the cell surface of mutant syn LD70 infections in the presence of 2-deoxy-D-glucose (data not shown). Using these cells as targets it would appear that the two immunogens induced antibodies specific for all three glycoproteins and that their relative proportions are roughly the same in each antiserum. In addition, a case can be made that the major share of the antibody specificity for immunolysis in both sera is against gC. Both antisera gave significant but weak cytolytic killing curves with the mutant syn LD70 glycosylation-inhibited target cells (Fig. 5A, B) and $50 \%$ endpoints of less than 40 each (Table 2). Since the DG form of $\mathrm{gD}$ is the only antigen on the surface of these target cells, this suggests that the contribution of anti-gD antibodies to the overall cytolytic reaction is small. Using glycosylation-inhibited KOS-infected cells as targets, cells in which $\mathrm{gB}$ is not available as a cytolytic antibody target, killing curves were found which were similar but slightly depressed, compared to those found when $\mathrm{gB}$ was available as a target (Fig. 5A, B). This is reflected in slightly lower $50 \%$ endpoints of 2229 and 640 as compared to 3880 and 844 (Table 2), suggesting that most of the cytolytic activity is due to $\mathrm{gC}$-specific antibody. This is supported by a much more precipitous drop in both killing curves and in the endpoints, 557 and 80 when mutant syn LD70-in- fected cells were used as targets. Since gC is removed as a target in the latter instance, the remaining cytolytic activity must largely be directed against $\mathrm{gB}$. Thus, the underglycosylated glycoproteins can act as immunogens for antibody reactive with both the mature and immature forms of the three glycoproteins in complementmediated immune cytolysis reactions.

The two sera also appear to be similar in virus-neutralizing activity (Table 2 ). The addition of complement enhanced neutralization by four to six $\log _{2}$ dilutions for both sera. Both sera are also equally effective against mutant syn LD70 virus particles suggesting that antibody specific for $\mathrm{gC}$ plays a minor role in neutralization.

All together, these findings show that the partially glycosylated glycoproteins are capable of inducing both cytolytic and neutralizing antibody and that complete glycosylation is not a necessary requirement for the immunogenicity of these HSV-1 glycoproteins.

Immunoprecipitation with Antibody Induced Against Cells Infected with HSV1 (KOS) in the Presence and Absence of 2-deoxy-D-glucose

These antisera were tested further for their antigenic specificities by immunoprecipitation of wild-type antigens from extracts of radioiodinated infected cells. 
As expected, the serum produced against untreated wild-type infected cells precipitated gC, gB, and gD (Fig. 6, lane 1). From the relative intensities of the bands the major share of the antibody is specific for gB. The serum produced against 2 -deoxyD-glucose-treated infected cells gave a weak precipitating reaction only with $\mathrm{gB}$ (Fig. 6, lane 2).

\section{DISCUSSION}

HSV-1-infected cells exhibit the virusspecified glycoprotein antigens $\mathrm{gC}, \mathrm{gB}$, and $\mathrm{gD}$ on the infected cell surface membrane (Spear, 1976). Cells infected in the presence of the glycosylation inhibitor 2-deoxyn-glucose do not synthesize the mature forms of the glycoproteins. Rather, lowermolecular-weight polypeptides accumulate (Courtney, 1976; Knowles and Person, 1976; Glorioso et al., 1980) which are antigenically related to the mature forms. In this report, immunoprecipitations employing antisera specific for the individual HSV glycoproteins established that gC contains antigenic sites cross-reactive with the underglycosylated polypeptide DG88, that $\mathrm{gB}$ is antigenically related to DG92 and that $\mathrm{gD}$ is antigenically related to DG53. The supposition that these proteins are underglycosylated forms related to the mature glycoproteins is strengthened by the demonstration of a genetic relationship between $\mathrm{gC}$ and DG88.

Cell surface radiolabeling, in combination with specific immunoprecipitation, demonstrated that the glycosylation inhibitor differentially affected the presentation of the viral glycoproteins on the cell surface membrane. The peptides antigenically related to $\mathrm{gC}$ were the predominant species on the cell surface, while smaller amounts of a $\mathrm{gD}$-related polypeptide were observed. Underglycosylated forms of $\mathrm{gB}$ were readily immunoprecipitated from cytoplasmic extracts, but these forms were not detected on the cell surface. Although the reason for this difference in transport is unknown, recent experiments using inhibitors affecting Golgi functions indicate that Golgi-associated glycosylation may be required for the presentation of pre-

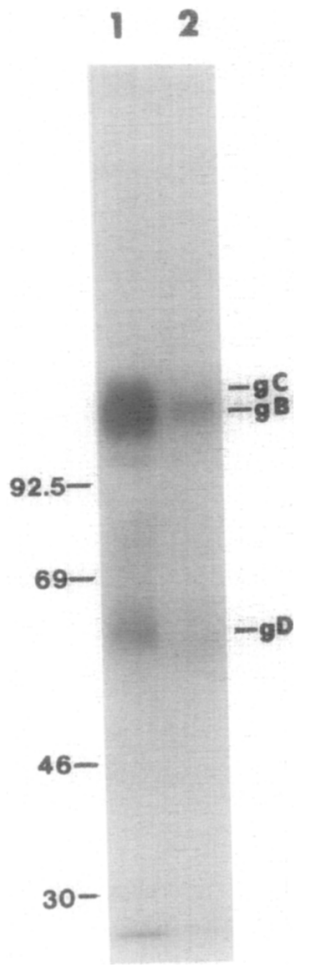

FIG. 6. Specificity of antisera produced against cells infected with wild-type virus in the presence and absence of 2-deoxy-D-glucose. Antisera were prepared as described in Fig. 5. Wild-type infected HEL cells were radioiodinated at $18 \mathrm{hr}$ after infection. Viral proteins were immunoprecipitated from cell lysates with antisera produced against untreated infected cells (lane 1) and treated infected cells (lane 2), electrophoresed on a $10 \%$ SDS-polyacrylamide gel, and visualized by autoradiography. Molecular weights $\left(\times 10^{-3}\right)$ are indicated on the left, and the positions of the glycoproteins on the right.

cursors of $\mathrm{gC}, \mathrm{gB}$, and $\mathrm{gD}$ on the cell surface (Johnson and Spear, 1982). Moreover, $\mathrm{gC}$ appears to contain both $\mathrm{N}$-linked and O-linked carbohydrate (Olofsson et al., 1981a). Glycosylation at O-linked sites requires the addition of $N$-acetylgalactosamine and does not contain a mannose core. Thus, it is unlikely that 2-deoxy-D-glucose affects glycosylation and chain elongation at the O-linked positions. These findings suggest that the differential expression of DG92 and DG88 on the cell surface relates to the presence of O-linked sugars on DG88 and that Golgi-related processing is a pre- 
requisite for sorting of HSV glycopeptides to the plasma membrane. Alternatively, the underglycosylated form of $\mathrm{gB}$ may simply aggregate in the cytoplasm and, thus, lack the conformation needed for insertion into the cell surface membrane.

The HSV glycoproteins are transported to the cell surface independently of one another. The absence of $\mathrm{gC}$ on the cell surface of mutant syn LD70-infected cells did not adversely affect the transport of $\mathrm{gB}$ and $\mathrm{gD}$. Similarly, the absence of $\mathrm{gB}$ on the cell surface in glycosylation inhibited wild-type HSV-1 (KOS) infections did not prevent the transport of immature forms of $\mathrm{gC}$ and $\mathrm{gD}$ to the cell surface. In glycosylation-inhibited mutant syn LD70 infections, immature $\mathrm{gD}$ is transported to the cell surface in the absence of both $\mathrm{gC}$ and $\mathrm{gB}$. It is also clear from these findings that complete glycosylation is not a prerequisite for transport of some of the $\mathrm{HSV}$ glycoproteins, in particular $\mathrm{gC}$ and $\mathrm{gD}$, to the cell surface membrane.

Courtney et al. (1973) demonstrated that radiolabeled 2-deoxy-D-glucose becomes incorporated into the glycopeptide, excluding the mannosyl residues which normally attach en bloc as the mannose-rich core. Instead of the HSV-1-induced major glycoprotein region, containing primarily $\mathrm{gC}$ and $\mathrm{gA} / \mathrm{gB}$, Courtney (1976) detected a peptide band designated DG92 and a slightly faster migrating species referred to as VP123'. Our immunoprecipitation studies using monospecific antibodies showed that DG92 was antigenically related to $\mathrm{gB}$ while DG88 was related to $\mathrm{gC}$. The DG92 species detected in this and the Courtney (1976) report probably refer to the same gB-related antigen and VP123' may be the same species as DG88. Knowles and Person (1976) have reported the accumulation of three polypeptide bands in 2-deoxy-D-glucose-treated HSV-1-infected cells which were designated $\mathrm{A}, \mathrm{B}$, and $\mathrm{C}$. Based on the migration in SDS-polyacrylamide gels, proteins $\mathrm{A}$ and $\mathrm{B}$ may be related to DG92 and band C may be similar to DG88.

A 58k polypeptide was immunoprecipitated with anti-HSV-1 (KOS) antiserum and also comes down with monoclonal an- tibody specific for glycoprotein $\mathrm{D}$ from both metabolically and cell surface-labeled extracts of wild-type and mutant syn LD70 virus-infected cells. In the presence of 2 deoxy-D-glucose, the $58 \mathrm{k}$ species is not found, while the partially glycosylated form of $\mathrm{gD}$, DG53, could be detected on the surface membranes of infected cells. This gD-related form was present in low amounts compared to DG88, the immature form of $\mathrm{gC}$. The $\mathrm{gD}$ polypeptide was not found in cytoplasmic extracts of glycosylation-inhibited cells with any consistency. These observations suggest that the gD-related polypeptides are unstable in the cytoplasm and may be degraded in the absence of the carbohydrate side chains normally attached to the polypeptides, as is the case for other glycoproteins (Olden et al., 1978; Schwartz et al., 1976). Oligosaccharide branch chains on glycoproteins may protect them from proteolytic reactions (Blobel and Dobberstein, 1975). DG53 may be similar to $\operatorname{pgD}(52)$ (Pizer et al., 1980 ), a partially glycosylated intermediate of $\mathrm{gD}(58)$.

Earlier work demonstrated the necessity for the expression of viral gene products during infection by syncytial variants of HSV for the occurrence of cell fusion (Manservigi et al., 1977). Although virusencoded proteins directly responsible for the induction of fusion have not yet been identified with certainty, glycoprotein B has been implicated in this process in cells infected with HSV-1 mutants (I Iaffey and Spear, 1980). In the presence of 2-deoxyD-glucose, mutant syn LD70-infected cells no longer formed syncytia (J. Glorioso, unpublished observation), confirming earlier reports for other syncytial forming variants of HSV (Knowles and Person, 1976). Knowles and Person (1976) suggested that fully processed glycoproteins or at least fully processed $\mathrm{gB}$, are needed for syncytia formation. As reported here, $\mathrm{gB}$ is not found on the cell surface in the presence of glycosylation inhibitors. Thus, the failure to induce fusion may be due to the absence of the fusion molecule on the cell surface rather than the absence of carhohydrate on the polypeptide.

Pizer et al. (1980) reported on the effects 
of tunicamycin on HSV replication, providing evidence that viral glycoprotein synthesis is inhibited. They detected an $85 \mathrm{k}$ protein synthesized in the presence of tunicamycin. Peake et al. (1982) confirmed that the $85 \mathrm{k}$ polypeptide was an analog of pgC. However, they reported that viral antigens could not be detected on the surface membranes of tunicamycin inhibited infections. In contrast, Norrild and Pedersen (1982) reported that underglycosylated forms of $\mathrm{gC}$ and $\mathrm{gD}$ were present on the plasma membrane of tunicamycin-inhibited HSV-infected cells, although the gDrelated form was only observed in trace amounts. These latter findings are similar to those observed in the present study using the glycosylation inhibitor 2-deoxy-Dglucose. Moreover, underglycosylated forms of the glycoproteins antigenically related to $\mathrm{gC}$ and $\mathrm{gD}$ but not $\mathrm{gB}$ were identified on the surface membrane of cells infected with HSV-1 (KOS) in the presence of tunicamycin, supporting the findings of Norrild and Pedersen (1982) (J. Glorioso, unpublished observations).

Complement-mediated immune cytolysis provides another measure of the cell surface location of antigens. Cytolysis assays, using mouse polyclonal and monoclonal antisera, give results corroborating the immunoprecipitation studies. All three glycoproteins are reactive on the surface of uninhibited infected cells with monospecific antibodies, confirming the findings of Norrild et al. (1979) that $\mathrm{gC}, \mathrm{gB}$, and $\mathrm{gD}$ can function independently as cytolytic targets in immunolysis assays. Antibody specific for $\mathrm{gC}$ and $\mathrm{gD}$ sensitized glycosylation-inhibited infected cells to immunolysis, confirming the transport and incorporation on the cell surface of antigenically active DG88 and DG53, immature forms of $\mathrm{gC}$ and $\mathrm{gD}$. Anti-gB antibody failed to lyse these cells, in correlation with the absence on the cell surface of DG92, the underglycosylated form of $\mathrm{gB}$. It appears that complete glycosylation is not a prerequisite for transport of $\mathrm{gC}$ and $\mathrm{gD}$ to the cell surface or for the preservation of antigenic determinants on these proteins recognized by cytolytic antibody.

In contrast to these observations on antibody-dependent complement-mediated immune cytolysis, Norrild and Pedersen (1982) reported that antibody specific for $\mathrm{gC}$ and $\mathrm{gB}$ did not sensitize tunicamycintreated HSV-infected cells to antibody-dependent cell-mediated immunolysis while antibody specific for gD gave only highly reduced amounts of cytolysis compared with uninhibited infected cells. These contrasting results may relate to the different inhibitors used in the two studies or to the different mechanisms of immune cytolysis employed. In both our study and in that of Norrild and Pedersen, at least some antigenic determinants reactive with precipitative antibodies were conserved in the underglycosylated forms of the major glycoproteins. The preservation of antigenicity in underglycosylated glycoproteins was also borne out by the fact that carbohydrate-deficient HSV-1 glycoproteins in 2deoxy-D-glucose-treated infected $3 \mathrm{~T} 3$ cells proved to be highly immunogenic, inducing the synthesis of cytolytic and neutralizing antibody.

Manipulations of the target cells by treatment with 2-deoxy-D-glucose or by infection with mutant syn LD70 virus makes it possible to present different subsets of the glycoproteins as targets. This permitted an analysis of the cytolytic antibody activities directed against the individual glycoproteins in antisera derived from immunizations involving untreated and glycosylation-inhibited infected cells. The data show that the relative cytolytic antibody specificities of the two sera are similar. The infected cells induce cytolytic antibody against each of the three antigens. The major cytolytic antibody activity appears to be directed against $\mathrm{gC}$, a minor portion against $\mathrm{gD}$, and the remainder against $\mathbf{g B}$. In contrast, anti-gC antibody appears not to play a critical role in virus neutralization. Progeny virions from mutant syn LD70 infection, which presumably have no $\mathrm{gC}$ in their envelopes, are as sensitive to neutralization by both antisera as are the progeny of wild-type KOS infections. Glycoproteins $\mathrm{gB}$ and $\mathrm{gD}$ appear to play a more central role in viral neutralization (Cohen et al., 1978; Vestergaard, 1980) and both these antisera have 
about equivalent amounts of neutralizing antibody specific for these glycoproteins. The neutralizing activity of both sera was greatly enhanced by complement, indicating that the difference in specificity between the neutralizing and cytolytic activities is not a consequence of differences in ability to fix complement.

In contrast to relatively good cytolytic and neutralizing activities, the serum induced by immunization with 2-deoxy-Dglucose inhibited cells appears to have poor immunoprecipitating activity. The major specificity of the precipitating activity of both sera is against $\mathrm{gB}$, while the cytolytic activity is primarily against gC. Both antisera have equally good virus-neutralizing activity, in which anti-gC antibody plays a minor role. Thus, these three tests of antibody activity, immune cytolysis, virus neutralization, and immunoprecipitation, fail to correlate with each other qualitatively and quantitatively. These findings suggest that different populations of antibodies in the same serum carry out these different functions.

In summary, evidence is presented that the underglycosylated forms of the HSV1 glycoproteins retain both antigenicity and immunogenicity, suggesting that many of the antigenic sites are localized within the polypeptide backbone. Although carbohydrate does not appear to be essential for maintenance of antigenicity, it can not be ruled out that the carbohydrate moieties may play an important role in protein conformation and that some antigenic determinant sites are formed as a consequence of protein secondary structure.

\section{ACKNOWLEDGMENTS}

Financial assistance was provided by Public Health Service Grant NIH RR00200 from the Animal Resource Branch, DRR, and by NIH Grants AI17900 and AI18228. M.S.S. and S.D.M. were supported by Public Health Service Research Service Training Award 132GM-07315 from the National Institutes of Health.

\section{REFFRFNCFS}

Balachandran, N., HaRnish, D., Rawls, W. E., and BACCHETTI, S. (1982). Glycoproteins of herpes simplex virus type 2 as defined by monoclonal antibodies. J. Virol 44, 344-355.
BAuCKe, R. B., and Spear, P. G. (1979). Membrane proteins specified by herpes simplex viruses. $\mathrm{V}$. Identification of an Fc-binding glycoprotein. $J$. Virol. 32, 779-790.

Blobel, G., and Dobberstein, B. (1975). Transfer of proteins across membranes. 1. Presence of processed and unprocessed nascent immunoglobulin light chains on membrane-bound ribosomes of murine myeloma. $J$. Cell. Biol 67, 835-851.

Campadelli-Fiume, G., Sinirat.nt-Vatit.fiona, P., Cavrini, V., and Mannini-Palenzona, A. (1980). Selective inhibition of herpes simplex virus glycoprotein synthesis by a benz-amidinohydrazone derivative. Arch. Virol 66, 179-191.

Cohen, G. H., Katze, M., Hydrean-Stern, C., and EISENBERG, R. J. (1978). Type-common CP-1 antigen of herpes simplex virus is associated with a 59,000 -molecular-weight envelope glycoprotein. $J$. Virol. 27, 172-181.

Cohen, G. H., Long, D., and Eisenberg, R. H. (1980). Synthesis and processing of glycoproteins $\mathrm{gD}$ and $\mathrm{gC}$ of herpes simplex virus type $1 . J$. Virol. 36, 429439.

COURTNEY, R. J. (1976). Herpes simplex virus protein synthesis in the presenec of 2 -deoxy-D-glucose. $V i$ rology 73, 286-294.

Courtney, J. K., Steiner, S. M., and BenYesh-MelNICK, M. (1973). Effects of 2-deoxy-D-glucose on herpes simplex virus replication. Virology 52, 447455.

Eberle, R., and Courtney, R. J. (1980a). Preparation and characterization of specific antisera to individual glycoprotein antigens comprising the major glycoprotein region of herpes simplex virus type 1 . J. Virol. 35, 902-917.

Eberle, R., and Courtney, R. J. (1980b). gA and gB glycoproteins of herpes simplex virus type 1: Two forms of a single polypeptide. $J$. Virol. 36, 665-676.

Eisenberg, R. J., Hydrean-Stern, C., and Cohen, G. H. (1979). Structural analysis of the precursor and product forms of the type-common envelope glycoprotein D (CP-1 antigen) of herpes simplex virus type 1. J. Virol. 31, 608-620.

Glorioso, J. C., and SMith, J. W. (1977). Immune interactions with cells infected with herpes simplex virus: Antibodies to radioiodinated surface antigens. J. Immunol. 118, 114-121.

Glorioso, J. C., Levine, M., Holland, T. C., and Szczesiul, M. S. (1980). Mutant analysis of herpes simplex virus induced surface antigens: Resistance to complement-mediated immune cytolysis. $J$. Virol. 35, 672-681.

HafFEy, M. L., and Spear, P. G. (1980). Alterations in glycoprotein $\mathrm{gB}$ specified by mutants and their partial revertants in herpes simplex virus type 1 and relationships to other mutant phenotypes. $J$. Virol. 35, 114-128.

Heine, J. W., Honess, R. W., Cassai, E., and RoizMAN, B. (1974). Proteins specified by herpes simplex 
virus. XII. The virion polypeptides of type 1 strains. J. Virol 14, 640.

Holland, T. C. (1978). Ph.D. thesis, The Pennsylvania State University, University Park, Pa.

Holland, T. C., Marlin, S. D., Levine, M., and GloRIOso, J. (1982). Antigenic variants of herpes simplex virus selected with glycoprotein specific monoclonal antibodies. $J$. Virol, in press.

Honess, R. W., and RoIzMaN, B. (1974). Regulation of herpes virus macromolecular synthesis. I. Cascade regulation of synthesis of three groups of viral proteins. $J$. Virol. 14, 8-16.

Honess, R. W., and Rorzman, B. (1975). Proteins specified by herpes simplex virus. XII. Glycosylation of viral glycoproteins. J. Virol. 16, 1308-1326.

Hunt, L. A., Etchison, J. R., and Summers, D. F. (1978). Oligosaccharide chains are trimmed during synthesis of the envelope glycoprotein of vesicular stomatitis virus. Proc. Nat. Acad. Sci. USA 75, 754758.

Johnson, D. C., and Spear, P. G. (1982). Monensin inhibits the processing of herpes simplex virus glycoproteins. Their transport to the cell surface and the egress of virions from infected cells. $J$. Virol, in press.

Katz, F. N., Rothman, J. E., LINGaPPa, V. R., BLobel, G. and LoDish, H. F. (1977). Membrane assembly in vitro: Synthesis, glycosylation and asymmetric insertion of a transmembrane protein. Proc. Nat. Acad. Sci. USA 74, 3278-3282.

KnIPE, D. M., Baltimore, D.; and Lowish, H. F. (1977a). Maturation of viral proteins in cells infected with temperature-sensitive mutants of vesicular stomatitis virus. $J$. Virol 21, 1149-1158.

KNOWLES, R. W., and PERSON, S. (1976). Effects of 2deoxy-D-glucose, glucosamine and mannose on cell fusion and the glycoproteins of herpes simplex virus. J. Virol. 18, 644-651.

LAEMMLI, U. K. (1970). Cleavage of structural proteins during the assembly of the head of bacteriophage T4. Nature (London) 227, 680-684.

LoDish, H. F., WIRTH, D., and PorTer, M. (1980). Synthesis and assembly of viral membrane proteins. Ann. N. Y. Acad. Sci. 343, 319-337.

Manservigi, R., Spear, P. G., and Buchan, A. (1977). Cell fusion induced by herpes simplex virus is promoted and suppressed by different viral glycoproteins. Proc. Nat. Acad. Sci. USA 74, 3913-3917.

Marsden, H. S., Crombie, I. K., and SubaK-Sharpe, J. H. (1976). Control of protein synthesis in herpesvirus-infected cells: Analysis of the polypeptides induced by wild type and sixteen temperature-sensitive mutants of HSV strain 17. J. Gen. Virol. 31, 347-372.

Morgan, C., Rose, H. M., Holden, M., and Jones, E. P. (1959). Electron microscopic observations on the development of herpes simplex virus. $J$. Exp. Med. 110, 643-656.

NiI, S., Morgan, C., and Rose, H. M. (1968). Electron microscopy of herpes simplex virus. II. Sequence of development. $J$. Virol 2, 517-536.

Norrild, B., BJerrum, O. J., Ludwig, H., and VesTERGAARD, B. F. (1978). Analysis of herpes simplex virus type 1 antigens exposed on the surface of infected tissue culture cells. Virology 87, 307-316.

Norrild, B., and Pedersen, B. (1982). Effect of tunicamycin on the synthesis of herpes simplex virus type 1 glycoproteins and their expression on the cell surface. J. Virol 43, 395-402.

Norrild, B., Shore, S. L., Cromeans, T. L., and NaHMIAS, A. J. (1980). Participation of three major glycoprotein antigens of herpes simplex virus type 1 early in the infectious cycle as determined by antibody-dependent cell-mediated cytotoxicity. Infect. Immun. 28, 38-44.

NorriLd, B., Shore, S. L., and Nahmias, A. J. (1979). Herpes simplex virus glycoproteins: Participation of individual herpes simplex virus type 1 glycoprotein antigens in immunocytolysis and their correlation with previously identified glycoproteins. $J$. Virol 32, 741-748.

Olden, K., PratT, R. M., and Yamada, K. M. (1978). Role of carbohydrate in protein secretion and turnover: effects of tunicamycin on the major cell surface glycoprotein of chick embryo fibroblasts. Cell 13, 461-474.

Olofssun, S., Blomberg, J., and Lycke, E. (1981a). 0 -glycosidic carbohydrate-peptide linkages of herpes simplex virus glycoproteins. Arch. Virol. 70, 321-329.

Olofsson, S., JeANSSON, S., and LyCKe, E. (1981b). Unusual lectin-binding properties of a herpes simplex virus type 1-specific glycoprotein. J. Virol 38, 564-570.

Peake, M. L., Nystrom, P., and Pizer, L. I. (1982). A study of herpes simplex virus glycoprotein synthesis and insertion into plasma membranes. $J$. Virol. 42, 678-690.

Periera, L., Dondero, D., and Rolzman, B. (1982). Herpes simplex virus glycoprotein gA/B: Evidence that the infeeted Vero cell products comap and arise by proteolysis. J. Virol. 44, 88-97.

Person, S., Kousoulas, K. G., Knowles, R. W., Read, G. S., Holland, T. C., KelleR, P. M., and WARNER, S. C. (1982). Glycoprotein processing in mutants of HSV-1 that induce cell fusion. Virology 117, 293306.

Pizer, L. I., Cohen, G. H., and Eisenberg, R. J. (1980). Effect of tunicamycin on herpes simplex virus glycoproteins and infectious virus production. J. Virol. 34, 142-153.

Rothman, J. E., Bursztyn-PetTegrew, H., and Fine, R. E. (1980a). Transport of the membrane glycoprotein of vesicular stomatitis virus to the cell surface in two stages by clathrin-coated vesicles. $J$. Cell Biol. 86, 162-171.

Rothman, J. E., and FINE, R. E. (1980b). Coated vesicles transport newly synthesized membrane gly- 
coproteins from endoplasmic reticulum to plasma membrane in two successive stages. Proc. Nat. Acad. Sci. USA 77, 780-784.

Ruyechan, W. T., Morse, L. S., KNIPE, D. M., and RoIzman, B. (1979). Molecular genetics of herpes simplex virus. II. Mapping of the major viral glycoproteins and of the genetic loci specifying the social behavior of infected cells. $J$. Virol. 29, 677697.

Sandri-Goldin, R. M., Levine, M., and Glorioso, J. C. (1981). Method for induction of mutations in physically defined regions of the herpes simplex virus genome. J. Virol. 38, 41-49.

Sarmiento, M., Haffey, M., and Spear, P. G. (1979). Membrane proteins specified by herpes simplex viruses. III. Role of glycoprotein $\operatorname{VP}\left(\mathrm{B}_{g}\right)$ in virion infectivity. J. Virol. 29, 1149-1158.

SCHWARTZ, R. T., ROHRSCHNEIDER, J. M., and SCHMIDT, M. F. G. (1976). Suppression of glycoprotein formation of semliki forest, influenza, and avian sarcoma virus by tunicamycin. J. Virol. 19, 782-791.

Smith, J. W., and Glorioso, J. C. (1976). Effects of cross-immunization on monotypic antibody responses to herpes simplex virus types 1 and $2 . J$. Immunol. 116, 898-903.

Spear, P. G., and RoIzman, B. (1972). Proteins specified by herpes simplex virus. V. Purification and structural proteins of the herpes virion. J. Virol. 9, 143-159.

SPEAR, P. G. (1976). Membrane proteins specified by herpes simplex virus. I. Identification of four glycoprotein precursors and their products in type 1infected cells. $J$. Virol. 17, 991-1008.

StRuck, D. K., and LENNARZ, W. J. (1977), Evidence for the participation of saccharide-lipids in the synthesis of the oligosaccharide side chain of ovalbumin. J. Biol. Chem. 252, 1007-1013.

TABAS, I., SCHLESINGER, S., and KoRnFELD, S. (1979). The processing of high mannose oligosaccharides to form complex type oligosaccharides on the newly synthesized polypeptides of VSV G protein and the fG heavy chain. J. Biol. Chem. 253, 785-794.

TarTakofF, A. M., and Vassalli, P. (1977). Plasma cell immunoglobulin secretion: arrest is accompanied by alterations of the Golgi complex. J. Exp. Med. 146, 1332-1345.

Tartakoff, A. M., and Vassalli, P. (1978). Comparative studies of intracellular transport of secretory proteins. J. Cell Biol. 79, 694-707.

VESTERGAaRD, B. F. (1980). Herpes simplex virus antigens and antibodies: A survey of studies based on quantitative immunoelectrophoresis. Rev. Infect. Dis. 2, 899-913.

WAEChTER, C. J., and LENNARz, W. J. (1976). The role of polyprenol-linked sugars in glycoprotein synthesis. Annu. Rev. Biochem. 45, 95-112.

WeBER, K., and OSBORN, M. (1969). The reliability of molecular weight determinations by dodecyl sulfate-polyacrylamide gel electrophoresis. J. Biol. Chem. 244, 4406-4412. 